http://dx.doi.org/10.4314/jae.v16i2.16

\title{
Crop Farmers' Perception of and Adaptation to Climate Change in Orlu Agricultural Zone of Imo State, Nigeria
}

Ugwoke, F. O., Nnadi, F. N., Anaeto, C. F., Aja, O. O., and Nwakwasi, R. N. Department of Agricultural Extension

Federal University of Technology, Owerri

E-Mail: fogwoke@yahoo.com. (08037978560)

\begin{abstract}
Food insecurity is a big challenge which Nigeria is currently battling with. This is compounded by the negative effects of climate change on agricultural production, and by extension, rural development. This work was therefore designed to ascertain crop farmers' perception of, and adaptation to climate change in Orlu agricultural zone of Imo State. The objectives of the study were to: assess farmers' level of awareness of elements of climate change, ascertain the extent farmers perceived climate change in the zone, find out the various effects of climate change in the area as perceived by the farmers, and ascertain the adjustment strategies adopted by the farmers. Data were collected from one hundred and twenty (120) crop farmers randomly selected from the zone, using interview schedule. Percentage, means, frequency distribution as well as multiple regression model were used to analyze the data. Most of the farmers (98.33\%) experienced climate change in the area and that changes in rainfall pattern were most prominent. Farmers perceived reduced crop yield, drought and increased flooding, among others, as the greatest adverse effects of climate change. Some of the strategies adopted to combat the adverse effects included; adjustment in planting period, use of improved crop varieties, adoption of improved farming methods, among others. Age, farming experience, educational level and membership of social organizations were significant factors that influenced farmers' perception of climate change in the area. Some of the recommendations include; extension agents should advice farmers to adopt early planting and harvesting before adverse climate conditions get to their peak, government and non-governmental organizations should assist farmers with irrigation facilities so that they will not be solely dependent on rain fed agriculture, among others.
\end{abstract}




\section{Introduction}

Climate change refers to all changes in climate that has been persistent over time, be it as a result of human activities or natural variations. Ozor (2009) defines climate change as any significant change in climate over time, whether due to natural variability or as a result of human activity and is widely recognized as the most serious environmental threat facing our planet today. Such significant change, according to Wiggins and Wiggins (2006), may include any or all of the following, among others: unpredictable rainfall; rising temperatures and drought; increased likelihood of hazards such as floods, landslides and severe cycloids which may result in hurricanes and typhoons.

Agricultural production depends on weather and climate. Climate change can therefore, adversely affect agriculture in many ways. It brings about change in weather pattern that can cause serious repercussions by upsetting seasonal cycles, harming the ecosystem and water supply, causing food shortages, landslide, drought and incidence of pests and diseases. Early estimates suggest 4 - 24\% losses in production in the developed countries, and $14-16 \%$ losses in developing countries (IPCC, 1996). Climate change is a global challenge and issue of great concern in almost all continents of the world today. It has been anticipated that climate change will affect agriculture in many ways, both direct and indirect. Part of the direct effect will induce low income to farmers, unemployment and lack of interest in agriculture by the youth (Battish, et al., 2007).

Eboh (2009) notes that countries in sub-Saharan Africa, including Nigeria, are likely to suffer the most because of their greater reliance on climate-sensitive renewable natural resources sectors like agriculture. Also other authors have equally noted that Nigeria, like all the countries of sub-Saharan Africa, is highly vulnerable to the impacts of climate change (NEST, 2004, IPCC, 2004 and Apata, et al, 2004). Incidentally, climate change may result in the loss of biodiversity, may increase extinction rates for vulnerable species and may cause a decline in the viability of important ecosystems (McCarthy, et al, 2001)

Crop farmers need to and should respond to climate variabilities if food security will not be seriously threatened. Over the years, farmers have been responding to climate change through adaptation, which is the process by which ecological, social or economic systems adjust in response to actual or expected climatic stimuli and their effects or impacts (Smith, et al., 2001). Therefore, adaptation to climate change refers to activities that reduce the negative impacts of climate change and/or takes advantage of new opportunities that may be presented. NEST (2004) suggested a number of adaptation measures to reduce the effects of climate change on crops. These include:

- Diversification to new plant species and varieties that would have higher resistance to anticipated temperature increase and reduced rainfall; 
- Improving local agricultural crop varieties that are well acclimatized and drought and pest resistant;

- Introduction of new irrigation schemes to dry land management to improve water use, particularly in the Sudan-Sahel zone;

- Encouraging farmers to use meteorological forecasts; etc.

Increasing climate variability is having profound impact on agriculture and adapting to climate change is a priority for smallholder farmers (Hailu, 2011). The result of research carried out by Eheazu (2011) in south east Nigeria, shows that many of the respondents, especially those living in the rural areas of Igbo land, are yet to understand the phenomena and attendant implications of global warming and climate change. He noted that such people are therefore neither reasonably aware of their individual and collective contributions to the incidence of the phenomena nor are they equipped mentally, practically and psychologically to properly respond to observable changes and impending hazards and disasters. Hence, this research was designed to investigate crop farmers' perception of and adaptation to climate change in Orlu Agricultural Zone of Imo State, Nigeria.

The specific objectives of the study include to:

1. assess the farmers' level of awareness of elements of climate change;

2. ascertain the extent farmers perceived climate change in the zone;

3. find out the various effects of climate change in the area as perceived by the farmers; and

4. ascertain the adjustment strategies adopted by the farmers.

\section{Hypothesis}

It was hypothesized that there is no significant relationship between the socioeconomic characteristics off the farmers and their perception of climate change in the area.

\section{Methodology}

The study was carried out in Orlu Agricultural zone of Imo State. The zone has twelve (12) Local Government Areas (LGAs) and crop production is common among farmers in the area.

A multi-stage random sampling technique was used to select one hundred and twenty (120) crop farmers for the study. In the first stage, four (4) LGAs were randomly selected. In the second stage, three (3) communities were also randomly selected from each of the four LGAs. In the final stage, ten (10) crop farmers were equally randomly selected from each of the communities, giving a total of 120 farmers. The ADP extension staff in the zone helped in the selection process and also assisted in data collection. 
Data were collected using structured and validated questionnaire and interview schedule. The literate crop farmers were given the questionnaire to fill while the interview schedule was used to collect information from the illiterate ones. Information was sought from the farmers on; their socio-economic characteristics, awareness of climate change, source(s) of information, extent of knowledge or awareness of climate change, perceived impacts of climate change and adaptation strategies.

Data were analysed using frequency distribution, percentages and mean. The hypothesis was tested using Ordinary Least Square multiple regression model.

\section{Results and Discussion}

\section{Socio-economic characteristics of the respondents}

Data in table 1 reveal that greater proportion (33.33\%) of the respondents fall within the age range of $41-50$ years while $31.67 \%$ are above 50 years of age. This is similar to the finding of Imbur, et al (2008) who reported that majority of the citrus farmers in Benue State fall within the age range of $40-49$ years and $50-$ 59 years respectively. The mean age of the farmers is 44.2 years, implying that they are in their middle ages and therefore active enough to adopt measures or technologies geared towards combating the challenges of climate change. Majority $(56.67 \%)$ of the respondents are females. This is not surprising since generally, women in the state engage in farming more than the men. Also, majority $(66.67 \%)$ of the respondents are married. Results also show that greater proportion $(35 \%)$ of the respondents had secondary school education while $33.33 \%$ had primary school education. This implies that majority of the respondents are farley literate and therefore are likely to readily adopt climate change adaptation and mitigation measures. Imbur, et al (2008) noted that the literacy level of the farmers is a very important variable as it influences the ability to properly comprehend new techniques and methods required to bring positive changes in knowledge, attitudes, skills and aspirations of the farmers. 
TABLE 1

Distribution of respondents by personal characteristics

\begin{tabular}{|c|c|c|c|}
\hline Characteristics & Frequency & Percentage & Mean \\
\hline \multicolumn{4}{|l|}{ Age (Years) } \\
\hline $21-30$ & 12 & 10.00 & \\
\hline $31-40$ & 30 & 25.00 & \\
\hline $41-50$ & 40 & 33.33 & 44.2 years \\
\hline 51 and above & 38 & 31.67 & \\
\hline \multicolumn{4}{|l|}{ Sex } \\
\hline Male & 52 & 43.33 & \\
\hline Female & 68 & 56.67 & \\
\hline \multicolumn{4}{|l|}{ Marital status } \\
\hline Married & 80 & 66.67 & \\
\hline Single & 6 & 6.67 & \\
\hline Widow & 32 & 26.67 & \\
\hline \multicolumn{4}{|l|}{ Educational status } \\
\hline No formal education & 38 & 31.67 & \\
\hline Primary school education & 40 & 33.33 & \\
\hline $\begin{array}{l}\text { Secondary school } \\
\text { education }\end{array}$ & 42 & 35.00 & \\
\hline Tertiary education & - & - & \\
\hline \multicolumn{4}{|l|}{ Farming experience } \\
\hline $1-5$ years & 16 & 13.33 & \\
\hline $6-10$ years & 36 & 30.00 & \\
\hline $11-15$ years & 26 & 21.67 & 12.76 years \\
\hline $16-20$ years & 22 & 18.33 & \\
\hline Above 20 years & 20 & 16.67 & \\
\hline \multicolumn{4}{|l|}{ Household size } \\
\hline $1-4$ & 34 & 28.33 & \\
\hline $5-8$ & 72 & 60.00 & 5.8 \\
\hline 9 and above & 14 & 11.67 & \\
\hline \multicolumn{4}{|l|}{$\begin{array}{l}\text { Organization } \\
\text { membership }\end{array}$} \\
\hline Member & 116 & 96.67 & \\
\hline Non-member & 4 & 3.33 & \\
\hline
\end{tabular}

The results further indicate that greater proportion (30\%) of the farmers have $6-$ 10 years farming experience while $21.67 \%$ have farming experience of $11-15$ years. The mean farming experience is about 13 years, implying that many of the farmers have been into farming long enough to observe climate changes and their impact. Majority (60\%) of the respondents have household size of $5-8$ persons while the mean household size is about 6 persons. This implies a moderate household size. Also, majority $(96.67 \%)$ of the farmers belong to one form of social organization or the other. The implication is that the farmers may obtain 
information about climate change from these organizations. Another implication is that it will be easy to reach these farmers in groups for purposes of information dissemination about climate change.

\section{Farmers' awareness and perception of climate change}

Table 2 reveals that all (100\%) of the farmers are aware of change in climate and that majority $(98.33 \%)$ observed the change through personal experience. Also a large proportion $(48.33 \%)$ of the farmers get information on climate change through their various social organizations. Only few of the farmers get information from mass media (31.67\%) and Extension service (20.00\%). The implication is that there is poor information dissemination on climate change through the mass media and Extension service to the farmers. This is buttressed by the fact that none of the farmers seems to be aware of what causes climate change. Unfortunately therefore, the farmers may be unconsciously contributing to global warming and climate change through indiscriminate burning of bushes and felling of trees without replacement.

Results also show that majority (75\%) of the farmers are aware of changes in rainfall pattern, while many are aware of changes in sunlight $(71.67 \%)$, temperature $(58.33 \%)$ and wind $(40 \%)$. Greater proportion (45\%) of the farmers perceive climate change "to a large extent" and "to a little extent" respectively, while only very few perceived it "to a very large extent" $(6.67 \%)$ and "to a very little extent" (3.33\%). 
TABLE 2

Distribution of respondents according to awareness of climate change; sources of awareness, causes of change, elements that change, and level of perception of change

\begin{tabular}{lcc}
\hline Variables & Frequency & Percentage \\
\hline Awareness of climate change & & \\
Yes & 120 & 100.00 \\
No & 0 & 0.00 \\
Sources of awareness/information* & 38 & 31.67 \\
Mass media & 58 & 48.33 \\
Social organization & 118 & 98.33 \\
Personal observation & 24 & 20.00 \\
Extension service & & \\
Awareness of causes of climate change & 0 & 0.00 \\
Yes & 120 & 100.00 \\
No & & \\
Awareness of elements that changed & 90 & 75.00 \\
Rainfall pattern & 4 & 3.33 \\
Relative humidity & 86 & 71.67 \\
Sunlight & 70 & 58.33 \\
Temperature & 48 & 40.00 \\
Wind & & \\
Level of perception of change & 8 & 6.67 \\
To a very large extent & 54 & 45.00 \\
To a large extent & 54 & 45.00 \\
To a little extent & 4 & 3.33 \\
To a very little extent & & \\
\hline
\end{tabular}

${ }^{*}$ Multiple responses 


\section{Adverse effects of climate change and adaptation measures}

Table 3 shows that majority (87.50\%) of the respondents perceive increased rainfall intensity as one of the effects of climate change. Others include: increased flooding $(85 \%)$, excessive heat $(73.33 \%)$, poor crop performance $(65.33 \%)$, increased soil erosion (66.67\%), windstorm (64.17) and pest and disease attack (51.67\%). The result is in line with the assertion of Wiggins and Wiggins (2006) that climate change may result in significant environmental threats like; rising temperature and drought, increased likelihoods of hazards such as floods, landslides and severe cycloids. Majority (66.67\%) of the farmers adopt diversification of farming activities as an adaptive strategy. Other strategies include adjustment in planting date $(60.83 \%)$, engagement in non-farm activities (53.3\%), among others.

TABLE 3

Distribution of respondents by their perception of adverse effects of climate change and adaptation strategies

\begin{tabular}{lcc}
\hline Variables & Frequency & Percentage \\
\hline Perceived adverse effects* & & \\
Increased rainfall intensity & 105 & 87.50 \\
Increased flooding & 102 & 85.00 \\
Excessive heat & 88 & 73.33 \\
Increased soil erosion & 80 & 66.67 \\
Increased wind storm & 77 & 64.17 \\
Increased disease outbreak/pest attack & 62 & 51.67 \\
Poor crop performance & 82 & 68.33 \\
Adaptation strategies* & & \\
Use of irrigation & 20 & 16.67 \\
Adjustment in date of planting & 73 & 60.83 \\
Use of improved crop varieties & 44 & 36.67 \\
Reduced investment in the farm & 32 & 26.66 \\
Diversification of farming activities & 80 & 66.67 \\
Engagement in non-farm activities & 64 & 53.33 \\
Increased use of farm input (e.g. fertilizer and & 48 & 40.00 \\
organic manure) & & \\
\hline *Multiple responses & &
\end{tabular}

\section{Hypothesis testing}

The hypothesis was that there is no significant relationship between the socioeconomic characteristics of the crop farmers and their perception of climate change. The regression result is as shown in table 4. Four functional forms of the model were tried in order to determine the most fit. The double-log functional form was chosen as the lead equation, based on the fact that it had the highest 
coefficient of multiple determinations $\left(R^{2}\right)$, the highest F-value and the highest number of significant variables.

\section{TABLE 4}

Ordinary least square multiple regression result of crop farmers perception of climate change and their socio-economic characteristics

\begin{tabular}{|c|c|c|c|c|}
\hline Explanatory variables & $\begin{array}{l}\text { Linear } \\
\text { function }\end{array}$ & $\begin{array}{l}\text { Semi-log } \\
\text { function }\end{array}$ & $\begin{array}{l}\text { Double-log } \\
\text { function }\end{array}$ & $\begin{array}{l}\text { Exponential } \\
\text { function }\end{array}$ \\
\hline $\begin{array}{l}\text { Constant } \\
R^{2} \\
\text { No. of Observations } \\
\text { Degree of freedom } \\
F-\text { Value }\end{array}$ & $\begin{array}{c}306.4291 \\
0.4613 \\
120 \\
52 \\
6.5901\end{array}$ & $\begin{array}{c}237.1826 \\
0.3968 \\
120 \\
52 \\
4.7238\end{array}$ & $\begin{array}{c}173.0927 \\
0.7817 \\
120 \\
52 \\
26.5884\end{array}$ & $\begin{array}{c}105.2601 \\
0.5108 \\
120 \\
52 \\
7.7629\end{array}$ \\
\hline$X_{1}(\operatorname{Sex})$ & $\begin{array}{l}-4.7815 \\
(-1.3872)\end{array}$ & $\begin{array}{l}-1.5928 \\
(-1.2982)\end{array}$ & $\begin{array}{c}-0.0917 \\
(-1.0713)\end{array}$ & $\begin{array}{c}-0.0098 \\
(-1.1807)\end{array}$ \\
\hline $\mathrm{X}_{2}$ (Age) & $\begin{array}{c}6.3999 \\
(1.1239)\end{array}$ & $\begin{array}{c}1.1169 \\
(2.7255)^{\star \star}\end{array}$ & $\begin{array}{c}0.0373 \\
(3.6559)^{\star \star}\end{array}$ & $\begin{array}{c}0.0055 \\
(1.1702)\end{array}$ \\
\hline $\mathrm{X}_{3}$ (Marital status) & $\begin{array}{c}5.4718 \\
(1.1332)\end{array}$ & $\begin{array}{l}1.18213 \\
(1.0656)\end{array}$ & $\begin{array}{c}0.0453 \\
(4.2336)^{\star \star}\end{array}$ & $\begin{array}{c}0.0069 \\
(1.2545)\end{array}$ \\
\hline $\mathrm{X}_{4}(\mathrm{Ed}$. Level) & $\begin{array}{c}8.6912 \\
(3.1224)^{\star \star}\end{array}$ & $\begin{array}{c}1.2281 \\
(2.9942)^{\star *}\end{array}$ & $\begin{array}{c}0.0227 \\
(2.7349)^{* *}\end{array}$ & $\begin{array}{c}0.0076 \\
(2.7143)^{\star *}\end{array}$ \\
\hline $\mathrm{X}_{5}$ (Farming exp.) & $\begin{array}{l}11.2998 \\
(1.0752)\end{array}$ & $\begin{array}{c}0.9718 \\
(1.0896)\end{array}$ & $\begin{array}{c}0.0659 \\
(2.7119)^{\star \star}\end{array}$ & $\begin{array}{c}0.0083 \\
(3.1923)^{\star *}\end{array}$ \\
\hline $\mathrm{X}_{6}(\mathrm{H} / \mathrm{H}$ size $)$ & $\begin{array}{c}8.2714 \\
(3.4682)^{* \star}\end{array}$ & $\begin{array}{c}2.7414 \\
(1.09637)\end{array}$ & $\begin{array}{c}0.0782 \\
(3.6037)^{\star *}\end{array}$ & $\begin{array}{c}0.0075 \\
(1.1719)\end{array}$ \\
\hline $\mathrm{X}_{7}$ (Org. mem.) & $\begin{array}{c}7.4163 \\
(3.5925)^{\star *}\end{array}$ & $\begin{array}{c}0.8413 \\
(1.0653)\end{array}$ & $\begin{array}{c}0.0836 \\
(2.6372)^{\star *}\end{array}$ & $\begin{array}{c}0.0092 \\
(3.1724)^{\star *}\end{array}$ \\
\hline
\end{tabular}

- Significant at 5\% (0.05)

${ }^{* *}$ Significant at $1 \%(0.01)$ 


\section{Figures in parenthesis are T-ratios or values}

Results show that the ages of the farmers, their marital status, educational status, farming experience, household size and membership of social organizations are significant variables and have direct relationship with crop farmers perception of climate change. Age, educational level, farming experience and membership of social organization are positive and significant. This implies that as one advances in age, the more he becomes aware and appreciates climate change. Also, the more educated the farmer is, the more he becomes aware of climate change and identifies it. Similarly, as one farms for a reasonable period of time, the more he gathers experience on climate change. Marital status and household size being positive and significant may imply information sharing in the family between or among family members on climate change. Sex of the farmers has no significant impact on their appreciation of climate change. Generally, however, the results imply that the socio-economic characteristics of the farmers influence their perception of climate change.

\section{Conclusion and Recommendations}

Results of the research showed that the farmers are aware of climate change but however, do not seem to know the cause(s). Their knowledge of climate change is mainly based on personal experience over time and information from social organizations. Elements of climate which they perceived to have changed significantly include rainfall pattern, sunlight and temperature. They seem to have perceived climate change to a fairly large extent. Perceived adverse effects include increased rainfall intensity, flooding, erosion, excessive heat and poor crop performance. Major adaptation strategies include; change in planting date, diversification of farming activities and engagement in non-farmer activities. Age of the farmers, their educational level, farming experience and membership of social organizations are significant variables that influenced the farmers' perception of climate change.

Based on the major findings, the following recommendations were made:

- Intensive capacity building workshops on climate change issues should be mounted by the Agricultural Development Programme (ADP) for Extension Agents so that they will be better equipped to enlighten the farmers.

- Government and non - governmental organizations should mount aggressive campaign through the mass media to enlighten the citizens on climate change issues, especially the causes and consequences

The above measures, and more, are necessary if we must ensure food security and meet the needed Millennium Development Goals (MDGs). 


\section{References}

Apata, T. G., Samuel, K. D. and Adeola, A. O. (2009). Analysis of climate change perception and adaptation among arable food crop farmers in South Western Nigeria. Paper presented at the conference of International Association of Agricultural Economics. Pp. 2 - 9.

Battish, S. A., David, S. T. and John, M. S. (2007). Assessing risk of climate variability and climate change for Indonesia rice agriculture. Proceedings of National Academy of Science of the United States of America. No. 19, Pp. $7752-7757$.

Eboh, E. C. (2009). Implications of climate change for economic growth and sustainable development in Nigeria. Enugu Forum Policy Paper 10. African Institute for Applied Economics. Nigeria.

Eheazu, B. A. (2011). Global warming and climate change: A sustainability alert to Ndigbo. Paper presented at the 2011 Ahiajioku lecture festival at Owerri, Imo State, Nigeria, on 25 ${ }^{\text {th }}$ November 2011.

Hailu, M. (2011). SPORE Magazine (editorial). Technical Centre for Agricultural and Rural Cooperation (CTA), Wagenigen, the Netherlands No. 156 December 2011.

Imbur, E. N., Agwu, A. E. and Akinnagbe, O. M. (2008). Adoption of citrus production technologies among farmers in Katsina-ala Local Government Area of Benue State, Nigeria. Journal of Agricultural Extension, Vol. 11, pp. $14-27$.

Intergovernmental Panel on Climate Change - IPCC (1996). Impacts, Adaptations and Mitigation of Climate Change. Scientific Technical Analysis Contribution of Working Group II to the IPCC Second Assessment Report. London, Cambridge University Press.

Intergovernmental Panel on Climate Change - IPCC (2004). Impact, Adaptations and Vulnerability. Contribution of Working Group II of the IPCC to the Third Assessment Report of IPCC. London, Cambridge University Press.

McCarthy, J. J., Ovald, F.C., Neil, A. L., David, J. D. and Kasey, S. W. (eds). (2000). Climate Challenge: Impacts, adaptation and vulnerability; Intergovernmental Panel on Climate Change, London. Cambridge University Press.

Nigerian Environmental Study Team - NEST (2004). Regional climate modeling and climate scenarios development in support of vulnerability and adaptations studies. Outcome of Regional climate modeling efforts over Nigeria, NEST, Ibadan, Nigeria. Pp. $12-20$. 
Ozor, N. (2009). Understanding climate change: Implication for Nigerian Agriculture, policy and Extension. Paper presented at the National conference on climate change and the Nigerian Environment. Organized by the Department of Geography, University of Nigeria, Nsukka. $29^{\text {th }}$ June $-2^{\text {nd }}$ July.

Smith, B. O., Pilifosova, I. Burton, B., Challenges, S,., Hug, R., Wein, G., Yohe (2001). "Adaptation to climate change in the context of sustainable development and equity.

Wiggins, S. and Wiggins, T. (2006). Climate change and Environment degradation: Risk and Adaptation Assessment, Teddington, U.K. Tear fund. 